\title{
Ruthenium Dihydrogen Complex for C-H Activation: Catalytic H/D Exchange under Mild Conditions
}

\author{
Martin H. G. Prechtl, ${ }^{[a, b]}$ Markus Hölscher, ${ }^{[a]}$ Yehoshoa Ben-David, ${ }^{[c]}$ Nils Theyssen, ${ }^{[b]}$ \\ David Milstein, ${ }^{[c]}$ and Walter Leitner*[a,b]
}

Keywords: Ruthenium dihydrogen complexes / H/D exchange / CH activation / Deuteration / DFT calculations

Catalytic H/D-exchange reactions were studied with $\left[\mathrm{Ru}(\mathrm{dtbpmp})\left(\eta^{2}-\mathrm{H}_{2}\right)(\mathrm{H})_{2}\right](\mathbf{1})$ as catalyst. Under mild reaction conditions $\left(25-75^{\circ} \mathrm{C}\right)$ a wide range of arenes and olefins undergo $\mathrm{H} / \mathrm{D}$ exchange with $\left[\mathrm{D}_{6}\right]$ benzene. A preference for protons at $\mathrm{sp}^{2}$ carbons was observed with conversions up to $>90 \%$ and significant regioselectivity in certain cases. For more reaction insights NMR-based kinetic studies were performed with naphthalene as substrate, revealing an activation energy of $15.8 \mathrm{kcalmol}^{-1}$ for the H/D exchange at the $\beta$-position. Furthermore, the key steps of the reaction mecha- nism were investigated by means of DFT calculations for both model complexes $\left(\mathrm{PMe}_{2}\right.$ donor sites) and real catalysts $\left(\mathrm{P} t \mathrm{Bu}_{2}\right.$ donor sites). The calculations resulted in Gibb's free activation energies in the range of $10-16 \mathrm{kcalmol}^{-1}$, indicating H/D exchange at the $\beta$-position of naphthalene to be clearly favoured over the $\alpha$-position, which is in full accordance with the experimental observations.

( Wiley-VCH Verlag GmbH \& Co. KGaA, 69451 Weinheim, Germany, 2008)

\section{Introduction}

Activation of $\mathrm{C}-\mathrm{H}$ bonds in hydrocarbons is one of the prominent challenges in modern homogeneous catalysis. For early evaluation of the potential of new catalyst precursors for this type of reaction, H/D-exchange processes are found to be useful for $\mathrm{C}-\mathrm{H}$ bond cleavage and formation. ${ }^{[1-3]}$ Other application fields of isotopic exchange reactions are well established, for example, in medicinal research and drug discovery processes where deuterated and tritiated labeled compounds are used to investigate metabolisms. ${ }^{[4-6]}$ Furthermore, there is an increasing interest in mild and selective catalytic H/D-exchange processes from a fundamental and application-oriented view.

H/D exchanges catalyzed by transition metals are usually performed with $\mathrm{D}_{2}$ or in deuterated organic solvents such as $\left[\mathrm{D}_{6}\right]$ benzene or $\left[\mathrm{D}_{6}\right]$ acetone, and in some cases deuterium oxide or $\left[\mathrm{D}_{4}\right]$ methanol can be used, unfortunately, in most cases the reaction temperatures are well above $100{ }^{\circ} \mathrm{C}$ or higher catalyst loadings are necessary. ${ }^{[4,7,8,9,10]}$ Organometallic complexes of iridium, rhodium, and ruthenium show a particular promising potential as catalysts. ${ }^{[4,8 \mathrm{a}, \mathrm{b}, 9 \mathrm{c}, \mathrm{d}, 10]}$

[a] Institute of Technical and Macromolecular Chemistry, RWTH Aachen University,

Worringer Weg 1, 52074 Aachen, Germany

Fax: +49-241-8022177

E-mail: leitner@itmc.rwth-aachen.de

[b] Max-Planck-Institut für Kohleforschung, Kaiser-Wilhelm-Platz 1, 45470 Mülheim/Ruhr, Germany

[c] Department of Organic Chemistry, Weizmann Institute of Science,

76100 Rehovot, Israel

Supporting information for this article is available on the WWW under http://www.eurjic.org or from the author.
As part of our ongoing interest in the catalytic properties of non-classical ruthenium hydrides, we have investigated several complexes of that type in recent years. ${ }^{[1,12]}$ For monomeric complexes we included bulky mono-dentate phosphanes and carbenes of NHC-type. ${ }^{[1,12 a]}$ With chelating bidentate phosphane ligands binuclear complexes were obtained, instead, bulky tridentate pincer ligands led to monomeric complexes. ${ }^{[12]}$ For example [Ru(IMes) $\left(\mathrm{PCy}_{3}\right)\left(\eta^{2}-\mathrm{H}_{2}\right)_{2}-$ $\mathrm{H}_{2}$ ] (2a) (IMes = 1,3-dimesityl-1,3-dihydro-2 $\mathrm{H}$-imidazol-2ylidene) and $\left[\mathrm{Ru}(\mathrm{IMes})_{2}\left(\eta^{2}-\mathrm{H}_{2}\right)_{2} \mathrm{H}_{2}\right](\mathbf{2 b})$ as carbene analogues of Chaudret's hexahydride $\left[\mathrm{Ru}\left(\mathrm{PCy}_{3}\right)_{2}\left(\eta^{2}-\mathrm{H}_{2}\right)_{2} \mathrm{H}_{2}\right]$ (3). ${ }^{[11]}$ In contrast to $\mathbf{3}$, complexes $\mathbf{2} \mathbf{a}$ and $\mathbf{2 b}$ showed a very high activity for the $\mathrm{H} / \mathrm{D}$ exchange between $\left[\mathrm{D}_{6}\right]$ benzene and several arenes. As recently communicated, we focus on the investigation in catalysis of ruthenium dihydrogen complexes bearing pincer-ligands with constrained geometry. ${ }^{[10,12 b]}$ The complex $\left[\mathrm{Ru}(\mathrm{dtbpmp})\left(\eta^{2}-\mathrm{H}_{2}\right) \mathrm{H}_{2}\right]$ (1) $($ dtbpmp $=2,6$-bis $[($ di-tert-butylphosphanyl)methyl $] p y r-$ idine) is readily accessible in good yields using the direct hydrogenation route shown in Scheme 1. ${ }^{[12]}$ Complex 1 was found to catalyze the $\mathrm{H} / \mathrm{D}$ exchange efficient at $50^{\circ} \mathrm{C}$. It should be noted that catalytic deuterium incorporation into
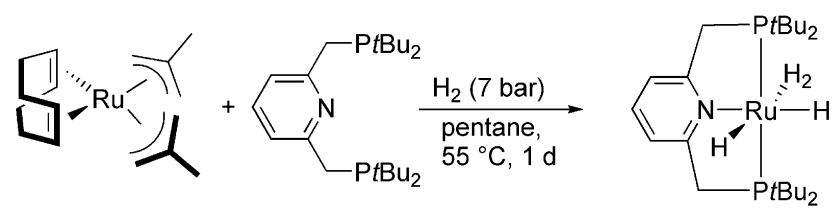

1

Scheme 1. Synthesis of $\mathbf{1}^{[12 b]}$ 
hetero aromatic compounds such as thiophene, 2,5-dimethylfuran and indol occurred very efficiently with $\mathrm{D}_{2} \mathrm{O}$ as the deuterium source. ${ }^{[10]}$

During these studies, it was observed that complex $\mathbf{1}$ is also an active catalyst for the H/D exchange between $\left[\mathrm{D}_{6}\right]$ benzene and aromatic substrates such as toluene $\mathbf{4}$ (Scheme 2).$^{[10,12 b]}$ In the present work we discuss the results of catalytic H/D exchange reactions between arenes and $\left[\mathrm{D}_{6}\right]$ benzene with the non-classical hydride complex $\left[\mathrm{Ru}(\mathrm{dtbpmp})\left(\eta^{2}-\mathrm{H}_{2}\right) \mathrm{H}_{2}\right](\mathbf{1})$ as catalyst precursor. At $50^{\circ} \mathrm{C}$, deuterium is effectively transferred from the solvent $\mathrm{C}_{6} \mathrm{D}_{6}$, into arenes with a significant regioselectivity for certain cases. The substrate scope included arenes, olefins and ferrocene and we complemented our previous mechanistic investigations, ${ }^{[10]}$ by including NMR kinetics and additional DFT calculations.

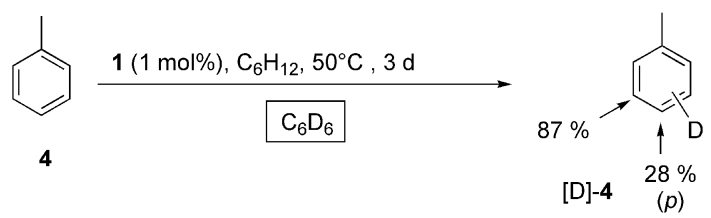

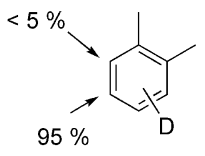

[D]-5

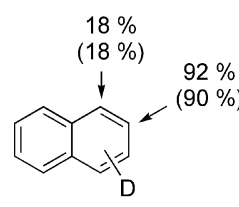

$[\mathrm{D}]-8(\mathrm{Hg})$

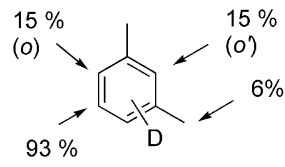

[D]-6

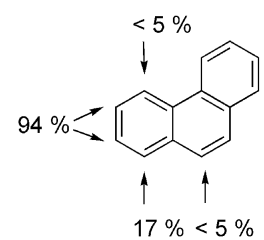

[D]-9

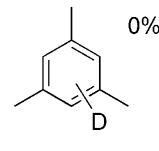

[D]-7

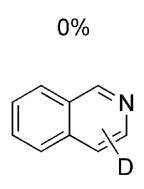

[D]-10

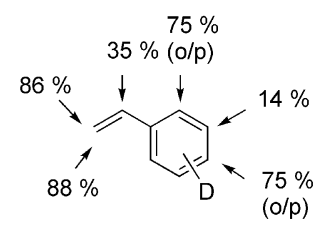

[D]-11

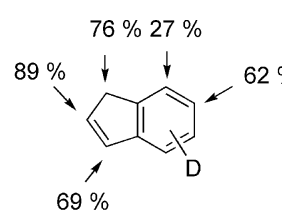

[D]-12

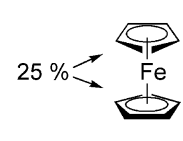

[D]-13
Scheme 2. Catalytic H/D exchange of aromatic compounds using $\mathrm{C}_{6} \mathrm{D}_{6}$ as the deuterium source and complex $\mathbf{1}$ as catalyst precursor. Reaction conditions (under argon): substrate 4-13: $1.0-1.6 \mathrm{mmol}$; $1 \mathrm{~mol}-\%$ Ru-cat. $1, \mathrm{C}_{6} \mathrm{D}_{6}(0.6 \mathrm{~mL}), \mathrm{C}_{6} \mathrm{H}_{12}(0.05 \mathrm{~mL}), t=3 \mathrm{~d}$; reaction temperature: $T=50{ }^{\circ} \mathrm{C}$; see Exp. Sect. for details. The values give the overall incorporation at the indicated positions.

\section{Results and Discussion}

As depicted in Scheme 2, selective H/D exchange occurred when treating toluene 4 with 1 mol- $\%$ of precatalyst
1 at $50{ }^{\circ} \mathrm{C}$ within three days. The incorporation took place with a clear preference for the meta position $(87 \%)$, while the para protons was much lower deuterated $(28 \%)$ and no significant incorporation was detected in the ortho position. The methyl group remained unreactive under the present conditions. In accordance to this observation, also other arenes were deuterated by treatment with 1 under similar conditions. Again, a significant chemo- and regio-selectivity was observed in certain cases. $o$-Xylene $\mathbf{5}$ was exclusively deuterated in the positions which are meta to the methyl groups ( $>95 \%)$. In case of $m$-xylene 6 the regio-selectivity is largely the same. The proton in the position that is meta to both methyl groups undergoes almost completely H/D exchange $(93 \%)$. The total sum of the deuterium incorporation is low $(15 \%)$ for all other aromatic positions as well for methyl groups (6\%). No H/D exchange was detectable with mesitylene 7 as substrate, even at higher catalyst loadings $(2 \mathrm{~mol}-\%)$. The treatment of naphthalene 8 under the same conditions as for $\mathbf{4}$ resulted preferably in $\beta$-deuteration $(90 \%)$ with a low amount of $\alpha$-deuteration $(18 \%)$.

The deuterium incorporation in phenanthrene $\mathbf{9}$ is also high and occurs almost exclusively in the two positions $\mathrm{C} 3$ and C4 (94\%). Interestingly, the heteroaromatic isoquinoline $\mathbf{1 0}$ was not deuterated under the conditions used in this study. This might be a result of the stronger coordination of the nitrogen functionality in isoquinoline 10 supported by DFT calculations for the two isomeric complexes 10a and 10b (Figure 1).
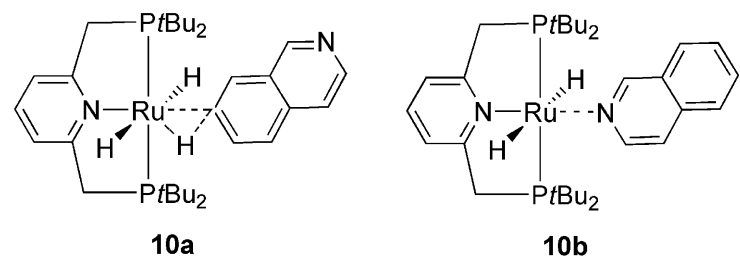

Figure 1. The isomeric complexes 10a and 10b.

The two isomers should be the ones that compete in the reaction mechanism for the H/D exchange (vide infra). ${ }^{[10]}$ The calculations show 10b to be more stable than 10a by $19.6 \mathrm{kcal} / \mathrm{mol}$. As a result the reaction only can take place if $10 \mathrm{~b}$ isomerizes to $10 \mathrm{a}$, which is an event that involves decoordination of isoquinoline and re-coordination in $\mathrm{C}-\mathrm{H}$ binding mode, which does not seem to be possible under the reaction conditions used in this work.

Aromatic substrates like styrene $\mathbf{1 1}$ or indene $\mathbf{1 2}$ are also highly deuterated with a very different chemo- and regioselectivity. The olefinic double bond is deuterated preferentially in styrene 11, with terminal positions being most reactive. Almost complete deuteration was observed in both terminal vinylic positions under standard conditions (86$88 \%$ ). Very high incorporation ( $75 \%$ ) was also obtained in the ortho and para positions of the aromatic ring. For indene $\mathbf{1 2}$ the deuteration is higher in the five-membered ring $(69-89 \%)$ than in the six-membered ring. Also the incorpo- 


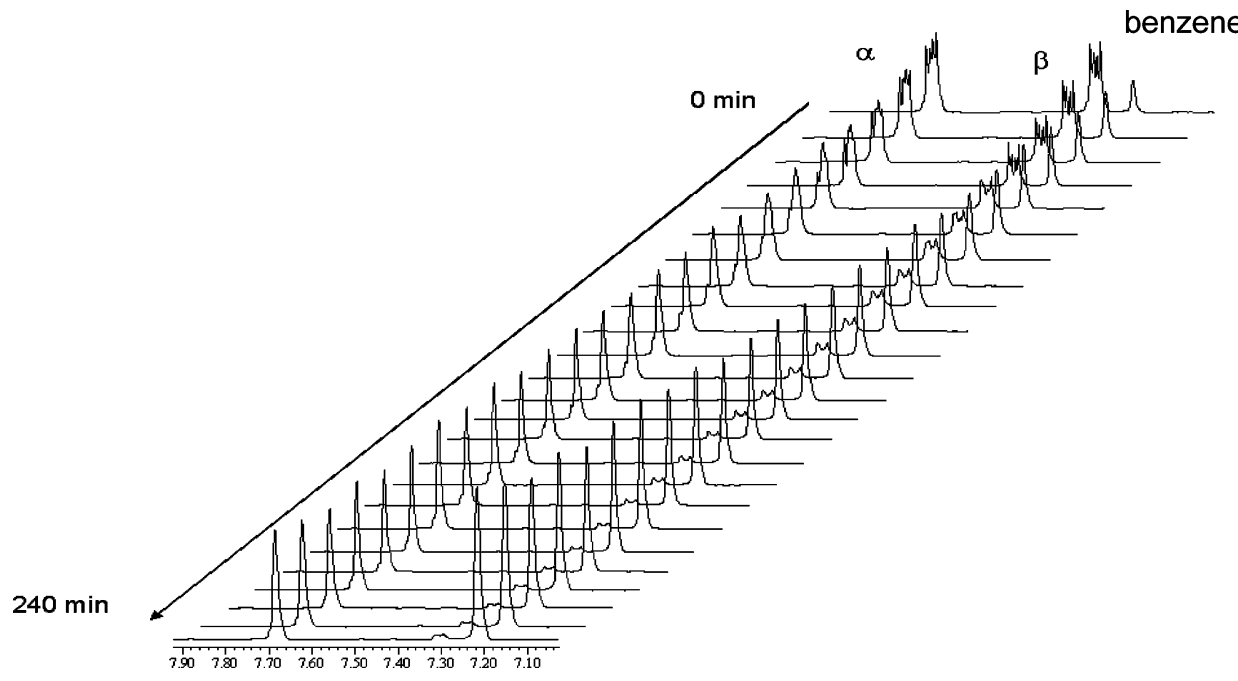

Figure 2. Time-resolved ${ }^{1} \mathrm{H}-\mathrm{NMR}$-monitoring of the H/D exchange in naphthalene 8 . Catalyst loading for $1: 4 \mathrm{~mol}-\%, T=70{ }^{\circ} \mathrm{C}$; conversion: $24 \%(\alpha), 90 \%(\beta)$ after $240 \mathrm{~min}$.

ration at the $\mathrm{sp}^{3}$ carbon is with $76 \%$ higher than in the positions of the six-membered ring. Finally, the treatment of ferrocene $\mathbf{1 3}$ showed also significant H/D exchange and about every fourth hydrogen was replaced by deuterium.

The properties of the catalytic system were studied in more detail with naphthalene $\mathbf{8}$. As previously reported for the $\mathrm{D}_{2} \mathrm{O}$ system, also in the present system the reaction was not influenced by the addition of mercury. ${ }^{[10]}$ This indicates a molecular organometallic mechanism. ${ }^{[13]}$ Under the conditions of Scheme 2 the results were identical within the experimental order in the presence of mercury $(\mathrm{Hg} / \mathrm{Ru}=10: 1$; $\alpha: 18 \% ; \beta: 92 \%) .{ }^{[13]}$ The kinetics of the reaction were than investigated by monitoring the H/D exchange at the $\beta$-position by ${ }^{1} \mathrm{H}$ NMR spectroscopy at different temperatures and catalyst loadings. Figure 2 shows the strong signal decrease of the $\beta$-positions, the lower decrease of the $\alpha$-positions and the increase of the benzene signal due to the $\mathrm{H} /$ $\mathrm{D}$ exchange. The increase of the deuterium incorporation at the $\beta$-position with precatalyst $1(7 \mathrm{~mol}-\%)$ at $50{ }^{\circ} \mathrm{C}$ resulted in deuterium incorporation of $79 \%$ after $6.5 \mathrm{~h}$ and $90 \%$ at $24 \mathrm{~h}$ respectively. In a second independent run a deuterium incorporation of $87 \%(6.5 \mathrm{~h})$ and $95 \%(24 \mathrm{~h})$ was obtained. Only $18 \%$ of the $\alpha$-positions were exchanged at that stage.

A detailed analysis of the spectra between 20 and $70 \mathrm{~min}$ reaction time $(<30 \%$ conversion) revealed an initial rate of $1.23 \times 10^{-6} \mathrm{~mol} \mathrm{~L}^{-1} \mathrm{~min}^{-1}$ for a reaction with $2 \mathrm{~mol}-\mathrm{-} \%$ of 1 at $50^{\circ} \mathrm{C}$ (Figure 3). The rate increased to $2.77 \times 10^{-6} \mathrm{~mol} \mathrm{~L}^{-1} \mathrm{~min}^{-1}$ upon doubling the catalyst loading to $4 \mathrm{~mol}-\%$. Further increase to $7 \mathrm{~mol}-\%$ gave a rate of $3.31 \times 10^{-6} \mathrm{~mol} \mathrm{~L}^{-1} \mathrm{~min}^{-1}$. From a double logarithmic plot of these data (Figure 4), a formal reaction order of 0.8 can be deduced for catalyst 1 . The data are most consistent with a first-order dependence up to concentrations corresponding to $4 \mathrm{~mol}-\mathrm{\%}$ and a deviation at higher loadings. This may be at least attributed to the formation of unreactive hydride bridged dimers. ${ }^{[12 a, 14]}$

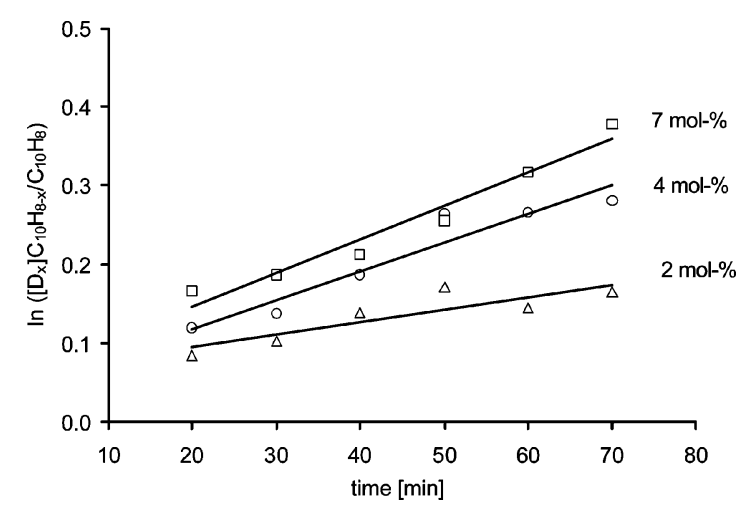

Figure 3. Logarithmic plot of the $\beta$-deuteration at different catalyst loadings at $50{ }^{\circ} \mathrm{C}$.

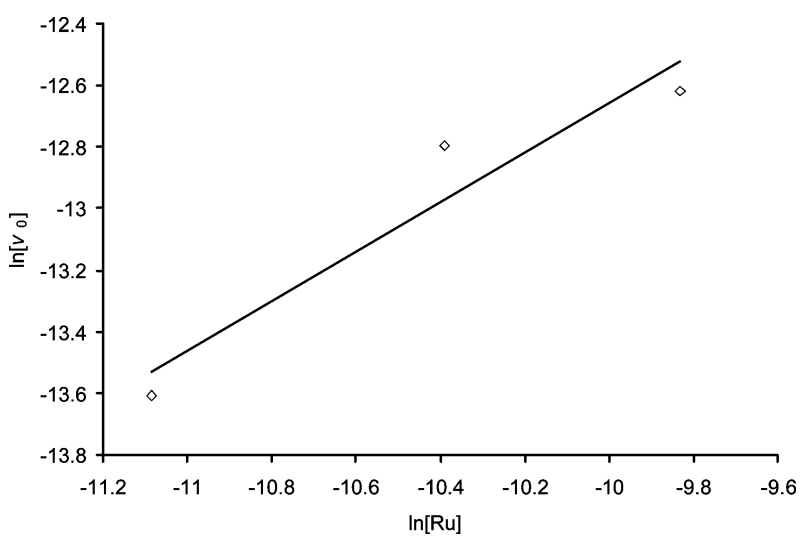

Figure 4. Double logarithmic plot to determine of the data from Figure 2 to determine the formal reaction order.

The influence of the reaction temperature was investigated at 4 mol- $\%$ loading of $\mathbf{1}$ in the range of $40-70{ }^{\circ} \mathrm{C}$ (Figure 5). The slope of the nearly linear increase between 20 and 80 min reaction time was used to determine the acti- 
vation energy of the process. From the Arrhenius plot, shown in Figure 6, the apparent activation energy is derived as $E_{\mathrm{A}}=15.8 \mathrm{kcal} \mathrm{mol}^{-1}$.

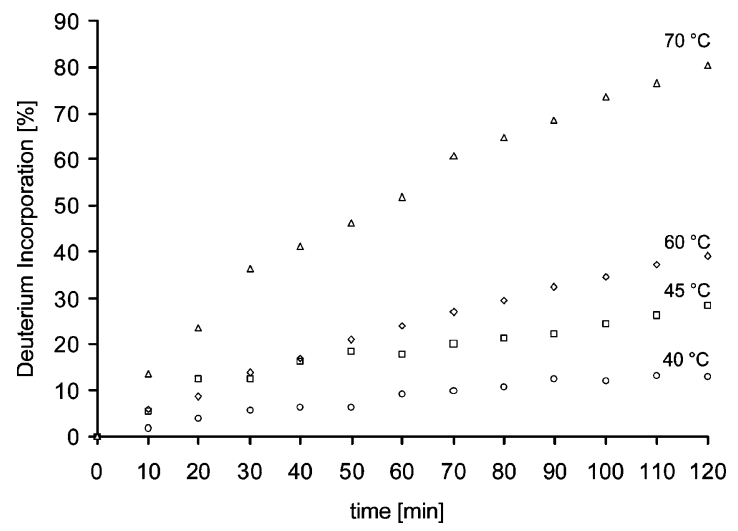

Figure 5. Temperature-dependent conversion/time profiles of the $\beta$ deuteration of naphthalene $\mathbf{8}$ catalysed by $\left[\mathrm{Ru}(\mathrm{dtbpmp})\left(\mathrm{H}_{2}\right) \mathrm{H}_{2}\right](\mathbf{1})$. Conditions: time-resolved ${ }^{1} \mathrm{H}-\mathrm{NMR}-\mathrm{monitoring}$, catalyst loading: 4 mol- $\%, T=40-70{ }^{\circ} \mathrm{C}$.

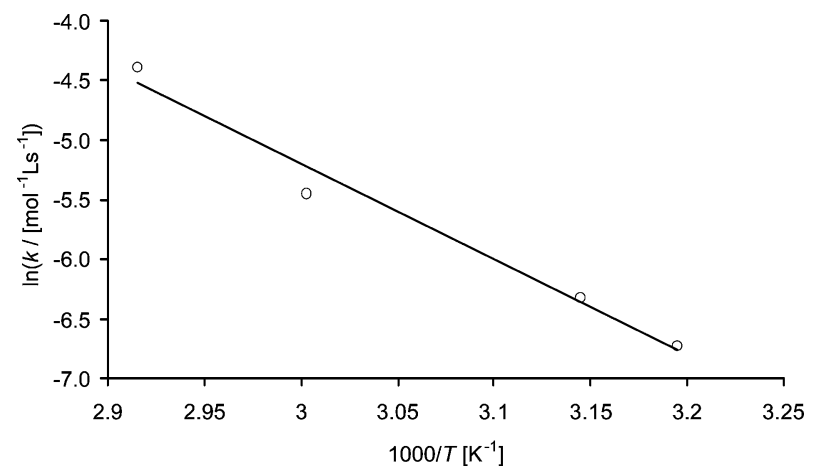

Figure 6. The Arrhenius plot of the $\beta$-deuteration catalyzed by [Ru(dtbpmp) $\left.\left(\mathrm{H}_{2}\right) \mathrm{H}_{2}\right]$ (1).

We have very recently reported a reaction mechanism for the H/D exchange for benzene and toluene based on DFT calculations. ${ }^{[10]}$ The mechanism relies on $\sigma$-bond metathesis as the key step. In a four-centre transition-state, one arene bonded hydrogen centre reacts with a metal bonded hydride centre forming metal bonded $\mathrm{H}_{2}$, while the carbon atom of the arene forms a single bond with the metal. In the present study, we have extended these calculations to the exchange of naphthalene as substrate in order to validate the consistency of this mechanistic model with the experimental results. Our previous study had shown that the difference between the activation energies of a H,H-transfer is roughly $1 \mathrm{kcal} / \mathrm{mol}$ lower than a H,D-transfer. Therefore only H,Htransfer processes are considered in this work for simplicity. The corresponding local minima (reactants $\left[\mathbf{1 4}_{\mathbf{a}}, \mathbf{1 4}_{\mathbf{b}}\right]$ and products $\left[\mathbf{1 5}_{\mathbf{a}}, \mathbf{1 5}_{\mathbf{b}}\right]$, a for $\alpha$ isomer, $\mathrm{b}=\beta$ isomer) as well as transition states ( $\mathbf{T S 1 4} \mathbf{a}_{\mathbf{a}, \mathbf{b}} \mathbf{- 1 5 _ { \mathbf { a } , \mathbf { b } }}$ ) were located for complexes containing the real ligand and for a model ligand, in which the $t \mathrm{Bu}$ groups of the real ligand were replaced by $\mathrm{Me}$ groups. The reason for computing the same reaction step for both types of ligands was to assess the steric influence of the real ligand and/or to find out if electronic reasons also play a role in this reaction. Scheme 3 shows the key steps of the exchange process for both ligand types: [Ru(dMepmp) $\left.\left(\eta^{2}-\mathrm{H}_{2}\right)\left(\mathrm{C}_{10} \mathrm{H}_{8}\right)\right]\left(\mathbf{1 4}_{\mathrm{m}}\right)\left(_{\mathrm{m}}\right.$ for model ligand) as well as the real catalyst complex $\left[\mathrm{Ru}(\mathrm{dtbpmp})\left(\eta^{2}-\mathrm{H}_{2}\right)\left(\mathrm{C}_{10} \mathrm{H}_{8}\right)\right]$

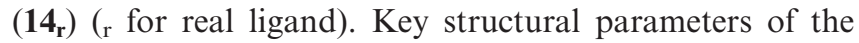
real complexes are shown in Figure 7.
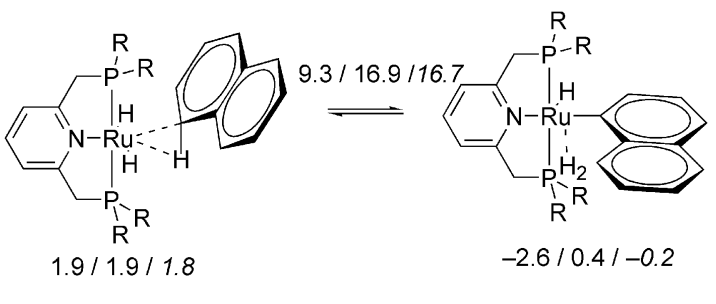

$14 \mathrm{am} / 14 \mathrm{ar}$

$15_{\mathrm{am}} / 15_{\mathrm{ar}}$

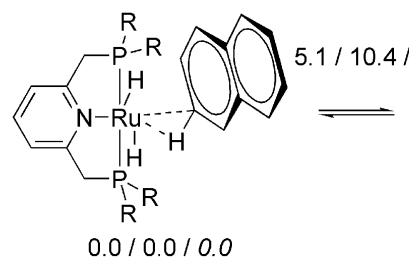

$14_{b m} / 14_{b r}$

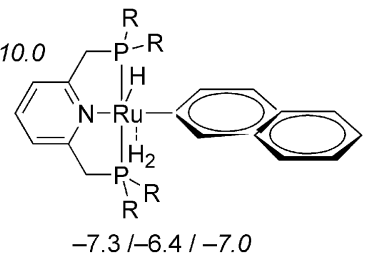

$15_{\mathrm{bm}} / 15_{\mathrm{br}}$
Scheme 3. Relative energies $\left(\Delta G, \Delta G^{\ddagger}, \mathrm{kcal} / \mathrm{mol}\right)$ of reactants, products and transition states (not shown) involved in $\mathrm{H} / \mathrm{H}$ exchange at naphthalene in $\alpha$ and $\beta$-positions (top to bottom) for model (m) and real (r) complexes (with basis sets B1 and B2, respectively). All calculations were carried out employing the B3LYP hybrid functional. $\Delta G$ and $\Delta G^{\star}$ values for calculations in the presence of solvent (IEF-PCM; solvent: benzene; only for complexes with the real ligand) are given in italics.

Complexes with the real ligand are discussed first (reaction of $\mathbf{1 4}$ ar and $\mathbf{1 4}$ br to $\mathbf{1 5}_{\mathrm{ar}}$ and $\mathbf{1 5} \mathrm{br}$, respectively, Figure 7): for the real complexes the relative stabilities of the reactants show the $\alpha$-isomer to be slightly more unstable than the $\beta$ isomer. However, this difference is small, i.e. at the reaction temperature chosen in this work both the $\alpha$ - and the $\beta$ isomer should be present in solution. In the transition states the planes of the naphthalene rings are rotated relative to the planes which are formed by the ruthenium centre, the two hydrogen centres attached to it and the nitrogen atom of the pincer backbone (i.e. rotation about the $\mathrm{Ru}-\mathrm{C}$ bond that is being formed, Figure 7). This rotation is necessary for the molecules to generate the appropriate geometry that enables hydrogen transfer. For the $\beta$-isomer $\left(\mathbf{T S 1 4} \mathbf{b r}_{\mathbf{b r}} \mathbf{- 1 5 _ { \mathbf { b r } }}\right)$ the naphthalene ring is rotated about the $\mathrm{C} 1-\mathrm{C} 2-\mathrm{H} 1-\mathrm{H} 2$ bond by $94^{\circ}$. However, for the $\alpha$-isomer ( $\mathbf{T S 1 4} \mathbf{a r}_{\mathbf{a r}} \mathbf{- 1 5}$ ) the naphthalene ring can only be rotated up to a value of $83^{\circ}$, on further rotation the repulsive interactions between the remote phenyl ring of that naphthalene unit and the methyl groups of one $t \mathrm{Bu}$ substituent will become too strong. Accordingly, the transition state geometry of the $\alpha$-isomer is less ideal resulting in a significantly higher activation energy $(15.0 \mathrm{kcal} / \mathrm{mol}$ relative to the reactant) compared to the $\beta$ isomer $(10.4 \mathrm{kcal} / \mathrm{mol}$ relative to the reactant $) .{ }^{[15]}$

Upon replacement of the $t \mathrm{Bu}$ groups in the real ligands by Me groups in the model ligands the steric strain should 


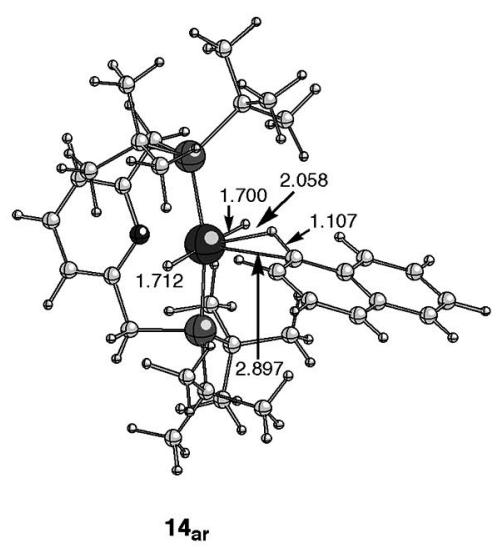

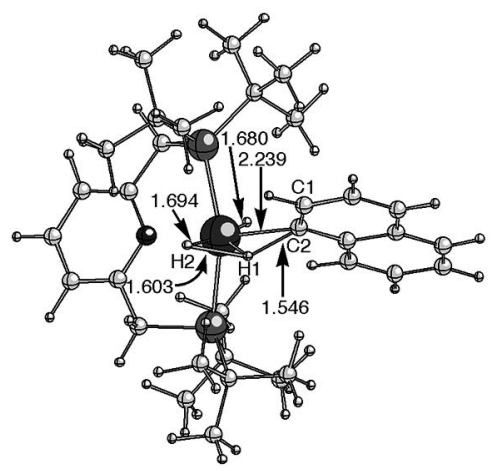

C1-C2-H1-H2: 83.2

TS-14 ar-15 ar

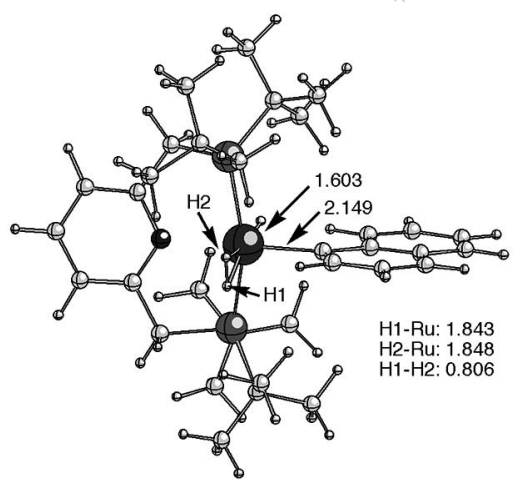

$15_{\text {ar }}$

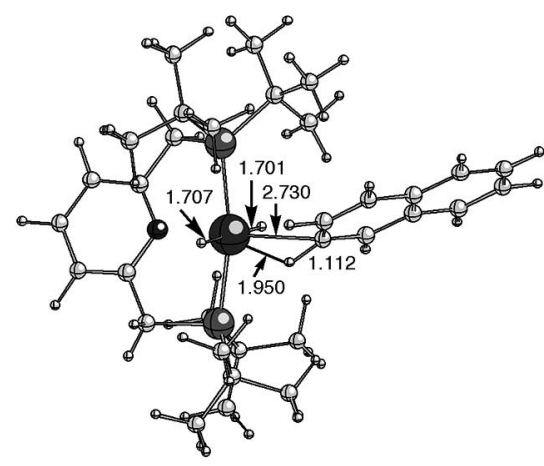

$14_{b r}$

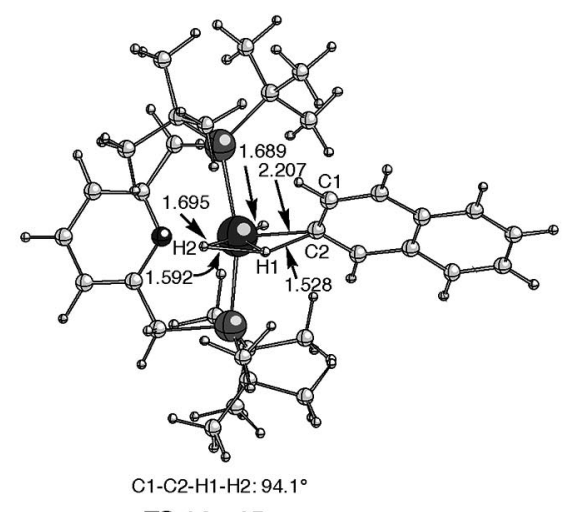

TS-14 $\mathrm{br}-15_{\mathrm{br}}$

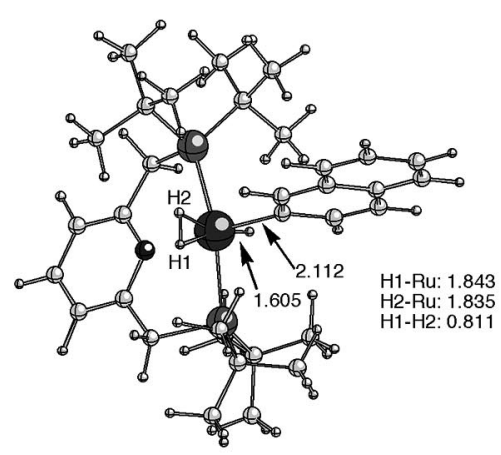

$15 \mathrm{br}$

Figure 7. Calculated structures (B3LYP/B2) of key intermediates and transition states for $\mathrm{H} / \mathrm{H}$ exchange at the $\alpha$ - (top) and $\beta$-positions (bottom) of naphthalene with selected atom distances $[\AA]$ and angles $\left[^{\circ}\right]$.

be minimized, i.e. the steric influence on the activation energies should be lowered. For the reaction of $\mathbf{1 4}_{\mathbf{a m}}$ to $\mathbf{1 5}_{\mathbf{a m}}$ the calculated Gibb's free activation energy amounts to $7.4 \mathrm{kcal} / \mathrm{mol}$ (relative to the reactant), while for the $\beta$-isomer it is $5.1 \mathrm{kcal} / \mathrm{mol}$ (Scheme 3), which indicates the steric factors play indeed a role in this reaction. Additionally and in contrast to the real complexes in the model complexes the naphthalene units of both isomers are rotated significantly further than the rotation in the real complexes. Also the rotation in the model complexes reaches approximately the same extent $\left(100^{\circ}\right.$ and $103^{\circ}$ for the $\alpha$ - and the $\beta$-isomer, respectively; not shown in Figure 7). These values are very similar to the corresponding benzene complex $\left(100^{\circ}\right.$, not shown) indicating that in the model complexes there is no sterically induced hindrance for this rotation that is associated with the remote part of the naphthalene ring. This is reflected in the energy difference of the two transition states: In the model complexes the difference is $2.3 \mathrm{kcal} /$ mol, while for the real complexes (vide supra) the difference is $4.6 \mathrm{kcal} / \mathrm{mol}$. Therefore it is reasonable to assume that both electronic and steric factors play a role in this reaction.

The structures of the transition states indicate furthermore that in the case of the $\alpha$-isomer the reaction has not made as much progress as for the $\beta$-isomer. For instance, in the real complexes the $\mathrm{Ru}-\mathrm{C}$ distance of the forming $\mathrm{Ru}-\mathrm{C}$ bond is significantly longer $(2.239 \AA)$ in the $\alpha$-isomer than in the $\beta$-isomer $(2.207 \AA)$. The $\mathrm{H}-\mathrm{H}$ bond, which is being formed reflects this tendency as well. In the $\alpha$-isomer the $\mathrm{H}-\mathrm{H}$ distance is $1.603 \AA$, while in the $\beta$-isomer the distance is slightly shorter (1.592 $\AA$ ) indicating as well that the process of bond formation has advanced further. Re-optimization of the real complexes in the presence of benzene as the solvent showed no significant changes in the energy profiles, indicating the solvent to have no drastic influence on the reaction. According to these results one would expect a significantly higher deuterium incorporation in the $\beta$-position, with no significant incorporation in the $\alpha$-position. This is in full accord with our experiments which showed that there is a clear preference of the $\beta$-position (up to $>95 \%$ deuteration) with respect to $\alpha$-deuteration $(<20 \%)$, which can be influenced by catalyst loadings, temperature and reaction time as previously discussed. ${ }^{[10]}$ Overall the experimental and computational data generate a consistent picture and show that the process is facile. Also the computationally derived activation barriers reflect the experimentally regioselectivity nicely. This regioselectivity has electronic grounds which are further improved by steric hindrance exerted by the $t \mathrm{Bu}$ groups at the ligand. 


\section{Conclusions}

We have shown that the non-classical ruthenium hydride complex $\mathbf{1}$ is an effective catalyst for the H/D exchange between arenes, olefins and $\left[\mathrm{D}_{6}\right]$ benzene at mild conditions. The incorporation shows significant chemo- and regio selectively in certain cases which is in agreement with our previous investigations with $\mathrm{D}_{2} \mathrm{O}$ as deuterium source. ${ }^{[10]}$ In conclusion, the $H / D$ exchange is independent from the deuterium source. The DFT calculations show significant differences in activation energies for the H/D exchange on naphthalene and support the experimentally observed preference for the deuteration in $\beta$-position. The NMR-kinetics resulted in an activation energy of $15.8 \mathrm{kcal} / \mathrm{mol}$ for the $\mathrm{H} /$ $\mathrm{D}$ exchange of the $\beta$-position in naphthalene. Further preparative studies towards catalytic applications of $\mathbf{1}$ and related complexes are underway.

\section{Experimental Section}

General: All reactions were performed under $\mathrm{Ar}$ and $\mathrm{H}_{2}$ atmospheres using Schlenk or glove box techniques. Solvents and substrates were purchased from Aldrich, Acros and Strem and were purified according to standard procedures. ${ }^{[16]}$ The PNP ligand dtbpmp was synthesised according the procedures by Milstein and Hartwig. ${ }^{[17,18]}$ The syntheses of the ruthenium complexes were carried out in a thick-walled Büchi Miniclave made of glass, similar to a Fischer-Porter bottle, via the direct-hydrogenation route starting from the $\left[\mathrm{Ru}(\mathrm{cod})\left(\eta^{3}-\mathrm{C}_{4} \mathrm{H}_{7}\right)_{2}\right]$ complex..$^{[10,12]}$

Caution! The use of pressurised gases can be hazardous and must only be carried out with suitable equipment and under appropriate safety precautions.

The deuterium incorporation was quantified by integration of the substrate/product signals in the ${ }^{1} \mathrm{H}$ NMR spectra in ratio to internal standard cyclohexane. The deuteration were verified by combination of ${ }^{13} \mathrm{C}-\mathrm{NMR}$ and ${ }^{2} \mathrm{H}$ NMR spectroscopy. The NMR spectra were recorded on Bruker AMX-300, Bruker AMX-400 (NMR kinetics) and Bruker DMX $600\left({ }^{2} \mathrm{H}\right.$ NMR) spectrometer.

Procedure for Catalytic H/D Exchange between Arenes and $\left[\mathrm{D}_{6}\right] \mathrm{Ben}-$ zene with $\left[\mathbf{R u}(\mathbf{d t b p m p})\left(\eta^{2}-\mathbf{H}_{2}\right) \mathbf{H}_{2}\right]$ as Catalyst, Exemplified for Toluene 4: A Teflon ${ }^{\circledR}$-capped Young NMR tube was filled with the catalyst 1 ( $5 \mathrm{mg}, 0.01 \mathrm{mmol}, 1 \mathrm{~mol}-\%)$, then $0.6 \mathrm{~mL}$ of $\mathrm{C}_{6} \mathrm{D}_{6}$ was added. The substrate $4(92 \mathrm{mg}, 1.0 \mathrm{mmol})$ and $0.05 \mathrm{~mL}$ cyclohexane (internal standard) were added. The ${ }^{1} \mathrm{H}$ NMR spectrum was measured immediately in order to determine the substrate/internal standard ratio as starting point of the reaction. The mixture was kept for three days at $50^{\circ} \mathrm{C}$, afterwards it was cooled to room temp. and the ${ }^{1} \mathrm{H}$ - and ${ }^{2} \mathrm{H}$ NMR spectra were measured (manual lock to $\left[\mathrm{D}_{6}\right]$ benzene; conversion: 87\% (meta), 28\% (para), < 5\% (ortho), $1 \%$ (Me). ${ }^{1} \mathrm{H}$ NMR $\left(300 \mathrm{MHz}, \mathrm{C}_{6} \mathrm{H}_{12} /\left[\mathrm{D}_{6}\right]\right.$ benzene, $25^{\circ} \mathrm{C}$, before H/D exchange): $\delta=7.1$ (23.5, meta-H), 7.0 (32.5, ortholpara-H), 2.1 (48.4, Me), 1.3 (100.0, $\mathrm{C}_{6} \mathrm{H}_{12}$, internal standard), $-7.5(\mathrm{Ru}-\mathrm{H}) \mathrm{ppm}$. ${ }^{1} \mathrm{H}$ NMR $\left(300 \mathrm{MHz}, \mathrm{C}_{6} \mathrm{H}_{12} /\left[\mathrm{D}_{6}\right]\right.$ benzene, $25^{\circ} \mathrm{C}$, after $\mathrm{H} / \mathrm{D}$ exchange): $\delta=7.07$ (3.0, meta-H), 6.8 (23.4, ortholpara-H), 2.1 (47.8, $\mathrm{Me}), \quad 1.3$ (100.0, $\mathrm{C}_{6} \mathrm{H}_{12}$, internal standard) ppm. ${ }^{2} \mathrm{H}$ NMR (600 MHz, $\mathrm{C}_{6} \mathrm{H}_{12} /\left[\mathrm{D}_{6}\right]$ benzene, $25^{\circ} \mathrm{C}$, after $\mathrm{H} / \mathrm{D}$ exchange): $\delta=7.3$ (meta-D), 7.2 (ortholpara-D), 2.4 (weak, Me) ppm.

o-Xylene 5: Ru-cat 1 ( $8 \mathrm{mg}, 0.016 \mathrm{mmol}, 1 \mathrm{~mol}-\%), T=50^{\circ} \mathrm{C}$, substrate: $170 \mathrm{mg}(1.6 \mathrm{mmol}), 0.5 \mathrm{~mL} \mathrm{C}_{6} \mathrm{D}_{6}, 0.1 \mathrm{~mL} \mathrm{C} \mathrm{C}_{12}, t=3 \mathrm{~d}$; conversion: $95 \%(\beta),<5 \%(\alpha),<5 \%(\mathrm{Me}) .{ }^{1} \mathrm{H}$ NMR $(300 \mathrm{MHz}$,
$\mathrm{C}_{6} \mathrm{H}_{12} /\left[\mathrm{D}_{6}\right]$ benzene, $25^{\circ} \mathrm{C}$, before H/D exchange): $\delta=7.0$ (48.6, $\alpha /$ B), $2.0(120, \mathrm{Me}), 1.3\left(100.0, \mathrm{C}_{6} \mathrm{H}_{12}\right.$, internal standard) $\mathrm{ppm} .{ }^{1} \mathrm{H}$ NMR (300 MHz, $\mathrm{C}_{6} \mathrm{H}_{12} /\left[\mathrm{D}_{6}\right]$ benzene, $25^{\circ} \mathrm{C}$, after $\mathrm{H} / \mathrm{D}$ exchange): $\delta=7.0(25.9 \alpha / \beta), 2.0(117.7, \mathrm{Me}), 1.3\left(100.0, \mathrm{C}_{6} \mathrm{H}_{12}\right.$, internal standard) ppm. ${ }^{2} \mathrm{H}$ NMR $\left(600 \mathrm{MHz}, \mathrm{C}_{6} \mathrm{H}_{12} /\left[\mathrm{D}_{6}\right]\right.$ benzene, $25^{\circ} \mathrm{C}$, after H/D exchange): $\delta=6.9$ ( $\beta-C D), 2.0$ (residue, Me) ppm. ${ }^{13} \mathrm{C} \mathrm{NMR}$ $\left(75 \mathrm{MHz}, \mathrm{C}_{6} \mathrm{H}_{12} /\left[\mathrm{D}_{6}\right]\right.$ benzene, $\left.25^{\circ} \mathrm{C}\right): \delta=136.5(\mathrm{CMe}), 130.1(\alpha-$ $C \mathrm{H}, \beta$ - $\mathrm{D}_{1}$-isotopomer), 130.1 ( $\alpha$ - $\mathrm{CH}$, meta- $\mathrm{D}_{2}$-isotopomer), 126.3 $\left(\beta-C H, \quad \beta-D_{1}\right.$-isotopomer), $126.0 \quad\left[\beta-C D, \quad \beta-D_{2}\right.$-isotopomer, $t$, $\left.{ }^{I} J(\mathrm{C}, \mathrm{D})=24.2 \mathrm{~Hz}\right] \mathrm{ppm}$.

m-Xylene 6: Ru-cat 1 ( $8 \mathrm{mg}, 0.016 \mathrm{mmol}, 1 \mathrm{~mol}-\%), T=50^{\circ} \mathrm{C}$, substrate: $170 \mathrm{mg}(1.6 \mathrm{mmol}), 0.5 \mathrm{~mL} \mathrm{C}_{6} \mathrm{D}_{6}, 0.1 \mathrm{~mL} \mathrm{C} \mathrm{H}_{12}, t=3 \mathrm{~d}$; conversion: $93 \%(\beta), 15 \%(\alpha), 6 \%(\mathrm{Me}) .{ }^{1} \mathrm{H}$ NMR $(300 \mathrm{MHz}$, $\mathrm{C}_{6} \mathrm{H}_{12} /\left[\mathrm{D}_{6}\right]$ benzene, $25^{\circ} \mathrm{C}$, before $\mathrm{H} / \mathrm{D}$ exchange): $\delta=7.1(10.8, \beta)$, $6.9(31.2, \alpha), 2.1(90.0, \mathrm{Me}), 1.3\left(100.0, \mathrm{C}_{6} \mathrm{H}_{12}\right.$, internal standard) ppm. ${ }^{1} \mathrm{H}$ NMR $\left(300 \mathrm{MHz}, \mathrm{C}_{6} \mathrm{H}_{12} /\left[\mathrm{D}_{6}\right]\right.$ benzene, $25^{\circ} \mathrm{C}$, after H/D exchange): $\delta=7.1(0.75, \beta), 6.9(26.4, \alpha), 2.1$ (84.7, Me), 1.3 (100.0, $\mathrm{C}_{6} \mathrm{H}_{12}$, internal standard) ppm. ${ }^{2} \mathrm{H}$ NMR $\left(600 \mathrm{MHz}, \mathrm{C}_{6} \mathrm{H}_{12} /\left[\mathrm{D}_{6}\right]-\right.$ benzene, $25^{\circ} \mathrm{C}$, after $\mathrm{H} / \mathrm{D}$ exchange): $\delta=7.1$ (s, $\left.\beta-C D\right), 7.0$ (residue, $\alpha-C D$ ), 2.1 (residue, Me) ppm.

Mesitylene 7: Ru-cat 1 ( $8 \mathrm{mg}, 1.6 \mathrm{mmol}, 1 \mathrm{~mol}-\%), T=50^{\circ} \mathrm{C}$, substrate: $192 \mathrm{mg}$ ( $1.6 \mathrm{mmol}), 0.5 \mathrm{~mL} \mathrm{C}_{6} \mathrm{D}_{6}, 0.1 \mathrm{~mL} \mathrm{C}_{6} \mathrm{H}_{12}, t=3 \mathrm{~d}$. No conversion detectable.

Naphthalene 8: The experiments $\mathbf{c}-\mathbf{j}$ were analysed by ${ }^{1} \mathrm{H}$ NMR every ten minutes. a) Ru-cat 1 ( $5 \mathrm{mg}, 0.01 \mathrm{mmol}, 1 \mathrm{~mol}-\%), T=$ $50{ }^{\circ} \mathrm{C}$, substrate: $128 \mathrm{mg}(1.0 \mathrm{mmol}), 0.6 \mathrm{~mL} \mathrm{C}_{6} \mathrm{D}_{6}, 0.05 \mathrm{~mL} \mathrm{C}_{6} \mathrm{H}_{12}$, $t=68 \mathrm{~h}$. - a) Ru-cat $1(5 \mathrm{mg}, 0.01 \mathrm{mmol}, 1 \mathrm{~mol}-\%), T=50^{\circ} \mathrm{C}$, substrate: $128 \mathrm{mg}(1.0 \mathrm{mmol}), 0.6 \mathrm{~mL} \mathrm{C}_{6} \mathrm{D}_{6}, 0.05 \mathrm{~mL} \mathrm{C}_{6} \mathrm{H}_{12}, t=$ $68 \mathrm{~h}$; conversion: $18 \%(\alpha), 90 \%(\beta)$. - b) Whitesides test: mercury (20 mg, $0.1 \mathrm{mmol}, 10 \mathrm{~mol}-\%$ ) was added to the reaction with a $100 \mu \mathrm{L}$ Hamilton Micro Syringe without a cannula; conversion: $18 \%(\alpha), 92 \%(\beta) .{ }^{1} \mathrm{H}$ NMR $\left(300 \mathrm{MHz}, \mathrm{C}_{6} \mathrm{H}_{12} /\left[\mathrm{D}_{6}\right]\right.$ benzene, $25{ }^{\circ} \mathrm{C}$, before H/D exchange): $\delta=7.6(17.1, \alpha), 7.2(16.3, \beta), 1.4(100.0$, $\mathrm{C}_{6} \mathrm{H}_{12}$, internal standard) ppm. ${ }^{1} \mathrm{H}$ NMR $\left(300 \mathrm{MHz}, \mathrm{C}_{6} \mathrm{H}_{12} /\left[\mathrm{D}_{6}\right]-\right.$ benzene, $25^{\circ} \mathrm{C}$, after $\mathrm{H} / \mathrm{D}$ exchange): $\delta=7.6(14.1, \alpha), 7.1(1.6, \beta)$, 1.4 (100.0, $\mathrm{C}_{6} \mathrm{H}_{12}$, internal standard) ppm. ${ }^{2} \mathrm{H}$ NMR $(600 \mathrm{MHz}$, $\mathrm{C}_{6} \mathrm{H}_{12} /\left[\mathrm{D}_{6}\right]$ benzene, $25^{\circ} \mathrm{C}$, after $\mathrm{H} / \mathrm{D}$ exchange): $\delta=7.7$ (residue, $\alpha), 7.3(\beta)$ ppm. ${ }^{31} \mathrm{P}$ NMR (122 MHz, $\mathrm{C}_{6} \mathrm{H}_{12} /\left[\mathrm{D}_{6}\right]$ benzene, $25^{\circ} \mathrm{C}$, after H/D exchange): $\delta=108.0$ (s, main signal) ppm. - c) Ru-cat 1 (7 mol- $\%$ ), $T=50{ }^{\circ} \mathrm{C}$, substrate: $0.5 \mathrm{mmol}, 0.6 \mathrm{~mL} \mathrm{C}_{6} \mathrm{D}_{6}, 0.05 \mathrm{~mL}$ $\mathrm{C}_{6} \mathrm{H}_{12}$; conversion: $79 \%(\beta) / 6.5 \mathrm{~h}, 90 \%(\beta) / 24 \mathrm{~h}$. - d) Ru-cat 1 (7 mol- $\%$ ), $T=50{ }^{\circ} \mathrm{C}$, substrate: $0.5 \mathrm{mmol}, 0.6 \mathrm{~mL} \mathrm{C}_{6} \mathrm{D}_{6}, 0.05 \mathrm{~mL}$ $\mathrm{C}_{6} \mathrm{H}_{12}$; conversion: $87 \%(\beta) / 6.5 \mathrm{~h}, 95 \%(\beta) / 24 \mathrm{~h}$. - e) Ru-cat 1 (4 mol- $\%$ ), $T=70{ }^{\circ} \mathrm{C}$, substrate: $0.5 \mathrm{mmol}, 0.6 \mathrm{~mL} \mathrm{C}_{6} \mathrm{D}_{6}, 0.05 \mathrm{~mL}$ $\mathrm{C}_{6} \mathrm{H}_{12}$; conversion: $65 \%(\beta) / 1.3 \mathrm{~h}, 90 \%(\beta) / 4 \mathrm{~h}$. - f) Ru-cat 1 (4 mol- $\%$ ), $T=60{ }^{\circ} \mathrm{C}$, substrate $0.5 \mathrm{mmol}, 0.6 \mathrm{~mL} \mathrm{C} \mathrm{D}_{6}, 0.05 \mathrm{~mL}$ $\mathrm{C}_{6} \mathrm{H}_{12}$; conversion: $30 \%(\beta) / 1.3 \mathrm{~h}, 64 \%(\beta) / 4 \mathrm{~h}$. - g) Ru-cat 1 (4 mol- $\%$ ), $T=45^{\circ} \mathrm{C}$, substrate: $0.5 \mathrm{mmol}, 0.6 \mathrm{~mL} \mathrm{C}_{6} \mathrm{D}_{6}, 0.05 \mathrm{~mL}$ $\mathrm{C}_{6} \mathrm{H}_{12}$; conversion: $21 \%(\beta) / 1.3 \mathrm{~h}, 48 \%(\beta) / 4 \mathrm{~h}$. - h) Ru-cat 1 (4 mol- $\%$ ), $T=40{ }^{\circ} \mathrm{C}$, substrate: $0.5 \mathrm{mmol}, 0.6 \mathrm{~mL} \mathrm{C}{ }_{6} \mathrm{D}_{6}, 0.05 \mathrm{~mL}$ $\mathrm{C}_{6} \mathrm{H}_{12}$; conversion: $11 \%(\beta) / 1.3 \mathrm{~h}, 22 \%(\beta) / 4 \mathrm{~h}$. i) Ru-cat 1 (2 mol$\%), T=50{ }^{\circ} \mathrm{C}$, substrate: $0.5 \mathrm{mmol}, 0.6 \mathrm{~mL} \mathrm{C}_{6} \mathrm{D}_{6}, 0.05 \mathrm{~mL} \mathrm{C}_{6} \mathrm{H}_{12}$; conversion: $15 \%(\beta) / 1.2 \mathrm{~h}$. - j) Ru-cat 1 (4 mol- $\%), T=50{ }^{\circ} \mathrm{C}$, substrate: $0.5 \mathrm{mmol}, 0.6 \mathrm{~mL} \mathrm{C}_{6} \mathrm{D}_{6}, 0.05 \mathrm{~mL} \mathrm{C}_{6} \mathrm{H}_{12}$; conversion: $28 \%$ $(\beta) / 1.3 \mathrm{~h}, 54 \%(\beta) / 4 \mathrm{~h}$.

\section{Phenanthrene 9}

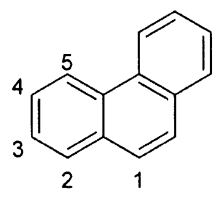


Ru-cat 1: $5 \mathrm{mg}(0.01 \mathrm{mmol}, 1 \mathrm{~mol}-\%), T=50^{\circ} \mathrm{C}$, substrate: $178 \mathrm{mg}$ (1.0 mmol), $0.5 \mathrm{~mL} \mathrm{C}_{6} \mathrm{D}_{6}, 0.05 \mathrm{~mL} \mathrm{C}_{6} \mathrm{H}_{12}, t=3 \mathrm{~d}$; conversion: $<$ $5 \%(\mathrm{C} 1), 7 \%(\mathrm{C} 2), 40 \%(\mathrm{C} 3, \mathrm{C} 4),<5 \%(\mathrm{C} 5) .{ }^{1} \mathrm{H} \mathrm{NMR}(300 \mathrm{MHz}$, $\mathrm{C}_{6} \mathrm{H}_{12} /\left[\mathrm{D}_{6}\right]$ benzene, $25^{\circ} \mathrm{C}$, before H/D exchange): $\delta=8.4$ (17.6, C5), 7.6 (15.9, C2), 7.4 (16.4, C1), 7.3 (31.5, C3/C4), 1.4 (100.0, $\mathrm{C}_{6} \mathrm{H}_{12}$, internal standard) ppm. ${ }^{1} \mathrm{H}$ NMR $\left(300 \mathrm{MHz}, \mathrm{C}_{6} \mathrm{H}_{12} /\left[\mathrm{D}_{6}\right]-\right.$ benzene, $25^{\circ} \mathrm{C}$, after $\mathrm{H} / \mathrm{D}$ exchange): $\delta=8.4$ (16.9, C5), 7.6 (13.2, C2), 7.4 (15.7, C1), $7.2(1.9, \mathrm{C} 3 / \mathrm{C} 4), 1.4\left(100.0, \mathrm{C}_{6} \mathrm{H}_{12}\right.$, internal standard) ppm. ${ }^{2} \mathrm{H}$ NMR $\left(600 \mathrm{MHz}, \mathrm{C}_{6} \mathrm{H}_{12} /\left[\mathrm{D}_{6}\right]\right.$ benzene, $25^{\circ} \mathrm{C}$, after H/D exchange): $\delta=7.3(\mathrm{C} 3 / \mathrm{C} 4) \mathrm{ppm}$.

Isoquinoline 10: Ru-cat $1(5 \mathrm{mg}, 0.01 \mathrm{mmol}, 1 \mathrm{~mol}-\%), T=50^{\circ} \mathrm{C}$, substrate: $129 \mathrm{mg}$ (1.0 mmol), $0.5 \mathrm{~mL} \mathrm{C}_{6} \mathrm{D}_{6}, 0.05 \mathrm{~mL} \mathrm{C}_{6} \mathrm{H}_{12}, t=$ 3 d. No conversion detectable.

Styrene 11

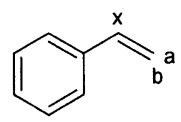

Ru-cat 1: $5 \mathrm{mg}(0.01 \mathrm{mmol}, 1 \mathrm{~mol}-\%), T=50{ }^{\circ} \mathrm{C}$, substrate: $104 \mathrm{mg}$ (1.0 mmol), $0.5 \mathrm{~mL} \mathrm{C}_{6} \mathrm{D}_{6}, 0.05 \mathrm{~mL} \mathrm{C}_{6} \mathrm{H}_{12}, t=3 \mathrm{~d}$; conversion: $14 \%$ (m), 74\% (o/p), 35\% (x), 86\% (a), 88\% (b). ${ }^{1} \mathrm{H}$ NMR (300 MHz, $\mathrm{C}_{6} \mathrm{H}_{12} /\left[\mathrm{D}_{6}\right]$ benzene, $25^{\circ} \mathrm{C}$, before $\mathrm{H} / \mathrm{D}$ exchange): $\delta=7.0(33.7, m)$, 6.8 (50.3, o/p), 6.3 (15.9, x), 5.3 (18.1, a), 4.8 (17.1, b), 1.2 (100.0, $\mathrm{C}_{6} \mathrm{H}_{12}$, internal standard) ppm. ${ }^{1} \mathrm{H}$ NMR $\left(300 \mathrm{MHz}, \mathrm{C}_{6} \mathrm{H}_{12} /\left[\mathrm{D}_{6}\right]-\right.$ benzene, $25^{\circ} \mathrm{C}$, after H/D exchange): $\delta=7.0(29.0, m), 6.8(12.8$, $o / p), 6.3(10.4, \mathrm{x}), 5.3(2.5, \mathrm{a}), 4.8(2.0, \mathrm{~b}), 1.3\left(100.0, \mathrm{C}_{6} \mathrm{H}_{12}\right.$, internal standard) ppm. ${ }^{2} \mathrm{H}$ NMR $\left(600 \mathrm{MHz}, \mathrm{C}_{6} \mathrm{H}_{12} /\left[\mathrm{D}_{6}\right]\right.$ benzene, $25^{\circ} \mathrm{C}$, after H/D exchange): $\delta=7.3(\mathrm{~m}), 7.1(\mathrm{o} / \mathrm{p}), 6.6(\mathrm{x}), 5.6$ (a), 5.1 (b) ppm.

Indene 12

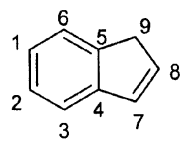

Ru-cat 1: (5 mg, $0.01 \mathrm{mmol}, 1 \mathrm{~mol}-\%), T=50{ }^{\circ} \mathrm{C}$, substrate: $116 \mathrm{mg}$ (1.0 mmol), $0.5 \mathrm{~mL} \mathrm{C}_{6} \mathrm{D}_{6}, 0.05 \mathrm{~mL} \mathrm{C}_{6} \mathrm{H}_{12}, t=3 \mathrm{~d}$; conversion: $62 \%$ (C1, C2), 27\% (C3, C6), 69\% (C7), 89\% (C8), 76\% (C9). ${ }^{1} \mathrm{H}$ NMR (300 MHz, $\mathrm{C}_{6} \mathrm{H}_{12} /\left[\mathrm{D}_{6}\right]$ benzene, $25^{\circ} \mathrm{C}$, before H/D exchange): $\delta=$ 7.3 (31.6, C1, C2), 7.3-7.1 (33.2, C3, C6), 6.7 (17.1, C7), 6.2 (14.9, C8), $3.0(42.0, \mathrm{C} 9), 1.4\left(100.0, \mathrm{C}_{6} \mathrm{H}_{12}\right.$, internal standard) $\mathrm{ppm} .{ }^{1} \mathrm{H}$ NMR $\left(300 \mathrm{MHz}, \mathrm{C}_{6} \mathrm{H}_{12} /\left[\mathrm{D}_{6}\right]\right.$ benzene, $25^{\circ} \mathrm{C}$, after $\mathrm{H} / \mathrm{D}$ exchange): $\delta=7.3$ (23.1, C1, C2), 7.3-7.1 (12.7, C3, C6), 6.7 (5.3, C7), 6.2 (1.6, C8), 3.0 (10.0, C9), $1.4\left(100.0, \mathrm{C}_{6} \mathrm{H}_{12}\right.$, internal standard) $\mathrm{ppm}$. ${ }^{2} \mathrm{H}$ NMR $\left(600 \mathrm{MHz}, \mathrm{C}_{6} \mathrm{H}_{12} /\left[\mathrm{D}_{6}\right]\right.$ benzene, $25^{\circ} \mathrm{C}$, after $\mathrm{H} / \mathrm{D}$ exchange): $\delta=7.3$ (C1, C2), 7.1-7.0 (C3, C6), 6.7 (C7), 6.2 (C8), 3.0 (C9) $\mathrm{ppm}$.

Ferrocene 13: Ru-cat 1 (5 mg, $0.01 \mathrm{mmol}, 1 \mathrm{~mol}-\%), T=50{ }^{\circ} \mathrm{C}$, substrate: $186 \mathrm{mg}(1.0 \mathrm{mmol}), 0.6 \mathrm{~mL} \mathrm{C}_{6} \mathrm{D}_{6}, 0.05 \mathrm{~mL} \mathrm{C}_{6} \mathrm{H}_{12}, t=3 \mathrm{~d}$; conversion: $25 \%$. ${ }^{1} \mathrm{H}$ NMR $\left(300 \mathrm{MHz}, \mathrm{C}_{6} \mathrm{H}_{12} /\left[\mathrm{D}_{6}\right]\right.$ benzene, $25{ }^{\circ} \mathrm{C}$, before H/D exchange): $\delta=4.0(35.2, \mathrm{Cp}-\mathrm{H}), 1.4\left(100.0, \mathrm{C}_{6} \mathrm{H}_{12}\right.$, internal standard) ppm. ${ }^{1} \mathrm{H}$ NMR $\left(300 \mathrm{MHz}, \mathrm{C}_{6} \mathrm{H}_{12} /\left[\mathrm{D}_{6}\right]\right.$ benzene, $25^{\circ} \mathrm{C}$, after H/D exchange): $\delta=3.7(26.5, \mathrm{Cp}-\mathrm{H}), 1.4\left(100.0, \mathrm{C}_{6} \mathrm{H}_{12}\right.$, internal standard) ppm. ${ }^{2} \mathrm{H} \quad \mathrm{NMR} \quad\left(600 \mathrm{MHz}, \mathrm{C}_{6} \mathrm{H}_{12} /\left[\mathrm{D}_{6}\right]-\right.$ benzene, $25^{\circ} \mathrm{C}$, after $\mathrm{H} / \mathrm{D}$ exchange): $\delta=4.0(\mathrm{Cp}-\mathrm{D}) \mathrm{ppm}$.

Computational Studies: The calculations reported herein were carried out with the Gaussian 03 program series (revision C02). ${ }^{[19]}$ Local minima and transition states were calculated employing the B3LYP hybrid functional. ${ }^{[20]}$ For model complexes (i.e. Me substituents at P) all nonmetal atoms were calculated using the TZVP basis set by Ahlrichs et al. ${ }^{[21]}$ in the implementation that is used in the Gaussian03 program, while for ruthenium the Stuttgart/ Dresden (311111/22111/411) basis set and associated ECP was used. ${ }^{[22]}$ This basis set is denoted B1. For real complexes (i.e. $t \mathrm{Bu}$ substituents at $\mathrm{P}$ ) all nonmetal atoms were calculated using the 6$31 \mathrm{G}(\mathrm{d})$ basis set. ${ }^{[23]}$ For the hydrogen centres bonded to the metal ( 2 centres) and the hydrogen centre of the naphthalene taking part in the reaction ( 1 centre) polarization functions were added, so that these 3 hydrogen centres were calculated with the 6-31G(d,p) basisset. For the ruthenium centre a $(441 / 2111 / 31 / 1)$ basis set ${ }^{[24 a]}$ in combination with a nonrelativistic small core ECP was used. ${ }^{[24 b]}$ This basis set is denoted B2. All stationary points were checked by frequency calculations to prove the existence of local minima (zero imaginary frequencies) or saddle points of order 1 (one imaginary frequency). Calculations (geometry optimization followed by frequency calculation, B3LYP/B2) in the presence of a solvent (benzene) were carried out using the self-consistent reaction field (SCRF) formalism, as implemented in Gaussian 03 employing the IEF-PCM (integral equation formulation of the polarizable continuum model). ${ }^{[25]}$ together with the united atom topological model for radii. Extra spheres for hydrogen were added for the hydrogen centres present at the Ru center and the hydrogen centre of the naphthalene involved in the reaction. During the geometry optimizations and the subsequent frequency calculations, the calculation of dispersion solute-solvent interaction energy, of repulsion solutesolvent interaction energy, and of the cavitation energy were switched off.

\section{Acknowledgments}

The Mynott group (R. Ettl, C. Wirtz, W. Wisniewski, M. Stachelhaus, B. Waßmuth and R. Mynott) is acknowledged for NMR and IR experiments. RWTH Aachen, Max-Planck-Gesellschaft and German-Israeli Project Cooperation (DIP G7.1) are gratefully acknowledged for financial support. We are also grateful for generous allocation of computer time by the Computation and Communication Centre of the RWTH Aachen.

[1] P. J. Jessop, R. H. Morris, Coord. Chem. Rev. 1992, 121, 155284.

[2] S. Sabo-Etienne, B. Chaudret, Coord. Chem. Rev. 1998, 178 180, 381-407.

[3] F. Kakiuchi, S. Murai, Acc. Chem. Res. 2002, 35, 826-834.

[4] a) J. T. Golden, R. A. Andersen, R. G. Bergman, J. Am. Chem. Soc. 2001, 123, 5837-5838; b) S. R. Klei, J. T. Golden, T. D. Tilley, R. G. Bergman, J. Am. Chem. Soc. 2002, 124, 20922093; c) S. R. Klei, T. D. Tilley, R. G. Bergman, Organometallics 2002, 21, 4905-4911; d) M. R. Skaddan, C. M. Yung, R. G. Bergman, Org. Lett. 2004, 6, 11-13; e) C. M. Yung, M. R. Skaddan, R. G. Bergman, J. Am. Chem. Soc. 2004, 126, 13033 13043.

[5] A. F. Thomas, Deuterium Labelling in Organic Chemistry 1971, Meridith Cooperation, New York.

[6] T. H. Lowry, K. S. Richardson, Mechanism and Theory in Organic Chemistry 1987, Harper and Row, New York.

[7] B. Rybtchinski, R. Cohen, Y. Ben-David, J. M. L. Martin, D. Milstein, J. Am. Chem. Soc. 2003, 125, 11041-11050.

[8] a) C. P. Lenges, P. S. White, M. Brookhart, J. Am. Chem. Soc. 1999, 121, 4385-4396; b) B. McAuley, M. J. Hockey, L. P. Kingston, J. R. Jones, W. J. S. Lockley, A. N. Mather, E. Spink, S. P. Thompson, D. J. Wilkinson, J. Labelled Compd. Radiopharm. 2003, 46, 1191-1204; c) J. Krüger, B. Manmontri, G. Fels, Eur. J. Org. Chem. 2005, 1402-1408; d) Q.-X. Guo, B.-J. Shen, H.-Q. Guo, T. Takahashi, Chin. J. Chem. 2005, 23, 341344. 
[9] a) A. G. Wong-Foy, G. Bhalla, X. Y. Liu, R. A. Periana, J. Am Chem. Soc. 2003, 125, 14292-14293; b) G. Bhalla, X. Y. Liu, J. Oxgaard, W. A. Goddard III, R. A. Periana, J. Am. Chem. Soc. 2005, 127, 11372-11389; c) W. J. Tenn III, K. J. H. Young, G. Bhalla, J. Oxgaard, W. A. Goddard III, R. A. Periana, J. Am. Chem. Soc. 2005, 127, 14172-14174; d) W. J. Tenn III, K. J. J. Young, J. Oxgaard, R. J. Nielsen, W. A. Goddard III, R. A. Periana, Organometallics 2006, 25, 5173-5175; e) S. M. Kloek, D. M. Heinekey, K. I. Goldberg, Angew. Chem. Int. Ed. 2007, 46, 4820-4822; Angew. Chem. 2007, 119, 4736-4738.

[10] M. H. G. Prechtl, M. Hölscher, Y. Ben-David, N. Theyssen, R. Loschen, D. Milstein, W. Leitner, Angew. Chem. 2007, 119, 2319-2322; Angew. Chem. Int. Ed. 2007, 46, 2269-2272.

[11] D. Giunta, M. Hölscher, C. W. Lehmann, R. Mynott, C. Wirtz, W. Leitner, Adv. Synth. Catal. 2003, 345, 1139-1145.

[12] a) S. Busch, W. Leitner, Chem. Commun. 1999, 2305-2306; b) M. H. G. Precht1, Y. Ben-David, D. Giunta, S. Busch, Y. Taniguchi, W. Wisniewski, H. Görls, R. J. Mynott, N. Theyssen, D. Milstein, W. Leitner, Chem. Eur. J. 2007, 13, 1539-1546.

[13] a) P. Foley, R. DiCosimo, G. M. Whitesides, J. Am. Chem. Soc. 1980, 102, 6713-6725; b) G. M. Whitesides, M. Hackett, R. L. Brainard, J.-P. P. M. Lavalleye, A. F. Sowinski, A. N. Izumi, S. S. Moore, D. W. Brown, E. M. Staudt, Organometallics 1985, 4, 1819-1830; c) C. Paal, W. Hartmann, Ber. Dtsch. Chem. Ges. 1918, 51, 711-737.

[14] a) B. Chaudret, J. Devillers, R. Poilblanc, Organometallics 1985, 4, 1727-1732; b) K. Abdur-Rashid, D. G. Gusev, A. J. Lough, R. H. Morris, Organometallics 2000, 19, 1652-1660.

[15] a) The difference of the experimentally derived activation energy for the $\beta$-isomer $(15.8 \mathrm{kcal} / \mathrm{mol})$ and the calculated one $(10.4 \mathrm{kcal} / \mathrm{mol})$ is assumed to be a result of a mixture of different experimental and theoretical error sources: The experimental error for the determination of $E_{\mathrm{a}}$ by NMR spectroscopy is estimated to be $\pm 2-3 \mathrm{kcal} / \mathrm{mol}$. It was shown before ${ }^{[10]}$ that the calculation of $\mathrm{H}, \mathrm{H}$ and $\mathrm{H}, \mathrm{D}$-exchanges yield to differences in activation energies of ca. $1 \mathrm{kcal} / \mathrm{mol}$, with the H,D-exchange yielding the higher activation energies. However, and presumably most important the combination of the B3LYP hybrid functional with a small basis set such as $6-31 \mathrm{~g}(\mathrm{~d})$ can result in much larger errors as was shown by Bauschlicher and Partridge ${ }^{[15 \mathrm{~b}]}$ yielding a mean average error of ca. $5.2 \mathrm{kcal} / \mathrm{mol}$ for atomization energies; b) C. W. Bauschlicher Jr, H. Partridge, J. Chem. Phys. 1995, 103, 1788-1791.

[16] D. D. Perrin, W. L. F. Armarego, Purification of Laboratory Chemicals 1988, Pergamon Press, London.

[17] D. Hermann, M. Gandelman, H. Rozenberg, L. J. W. Shimon, D. Milstein, Organometallics 2002, 21, 812-818.

[18] M. Kawatsura, J. F. Hartwig, Organometallics 2001, 20, 1960 1964.
[19] Gaussian 03, Revision B.03, M. J. Frisch, G. W. Trucks, H. B. Schlegel, G. E. Scuseria, M. A. Robb, J. R. Cheeseman, J. A. Montgomery Jr, T. Vreven, K. N. Kudin, J. C. Burant, J. M. Millam, S. S. Iyengar,J. Tomasi, V. Barone, B. Mennucci, M. Cossi, G. Scalmani, N. Rega, G. A. Petersson, H. Nakatsuji, M. Hada, M. Ehara, K. Toyota, R. Fukuda, J. Hasegawa, M. Ishida, T. Nakajima, Y. Honda, O. Kitao, H. Nakai, M. Klene, X. Li, J. E. Knox, H. P. Hratchian, J. B. Cross, V. Bakken, C. Adamo, J. Jaramillo, R. Gomperts, R. E. Stratmann, O. Yazyev, A. J. Austin, R. Cammi, C. Pomelli, J. W. Ochterski, P. Y. Ayala, K. Morokuma, G. A. Voth, P. Salvador, J. J. Dannenberg, V. G. Zakrzewski, S. Dapprich, A. D. Daniels, M. C. Strain, O. Farkas, D. K. Malick, A. D. Rabuck, K. Raghavachari, J. B. Foresman, J. V. Ortiz, Q. Cui, A. G. Baboul, S. Clifford, J. Cioslowski, B. B. Stefanov, G. Liu, A. Liashenko, P. Piskorz, I. Komaromi, R. L. Martin, D. J. Fox, T. Keith, M. A. Al-Laham, C. Y. Peng, A. Nanayakkara, M. Challacombe, P. M. W. Gill, B. Johnson, W. Chen, M. W. Wong, C. Gonzalez, J. A. Pople, Gaussian, Inc., Wallingford CT, 2004.

[20] a) A. D. Becke, J. Chem. Phys. 1993, 98, 5648 -5652; b) C. Lee, W. Yang, R. G. Parr, Phys. Rev. B 1988, 37, 785-789; c) S. H. Vosko, L. Wilk, M. Nusair, Can. J. Phys. 1980, 58, 1200; d) P. J. Stephens, F. J. Delvin, C. F. Chabalowski, M. J. Frisch, J. Phys. Chem. 1994, 98, $11623-11627$.

[21] a) A. Schäfer, H. Horn, R. Ahlrichs, J. Chem. Phys. 1992, 97, 2571-2577; b) A. Schäfer, C. Huber, R. Ahlrichs, J. Chem. Phys. 1994, 100, $5829-5835$.

[22] D. Andrae, U. Haessermann, M. Dolg, H. Stoll, H. Preuss, Theor. Chim. Acta 1990, 77, $123-141$; the basis set is denoted "Stuttgart RSC 1997" and was obtained from the Gaussian Basis Set Order Form at http://www.emsl.pnl.gov/forms/basisform.html.

[23] a) R. Ditchfield, W. J. Hehre, J. A. Pople, J. Chem. Phys. 1971, 54, 724; b) W. J. Hehre, R. Ditchfield, J. A. Pople, J. Chem. Phys. 1972, 56, 2257; c) P. C. Hariharan, J. A. Pople, Mol. Phys. 1974, 27, 209; d) M. S. Gordon, Chem. Phys. Lett. 1980, 76, 163; e) P. C. Hariharan, J. A. Pople, Theor. Chim. Acta 1973, $28,213$.

[24] a) G. Frenking, I. Antes, M. Böhne, S. Dapprich, A. W. Ehlers, V. Jonas, A. Neuhaus, M. Otto, R. Stegmann, A. Veldkamp, S. F. Vyboishchikov, Reviews in Computational Chemistry (Eds.: K. B. Lipkowitz, D. B. Boyd), Wiley-VCH, New York, 1996, vol. 8, 63-144; b) P. J. Hay, W. R. Wadt, J. Chem. Phys. 1985, $82,299$.

[25] J. Tomasi, B. Mennucci, R. Cammi, Chem. Rev. 2005, 105, 2999-3094.

Received: April 8, 2008 Published Online: June 25, 2008 